\title{
"Is Abbot Isidore also among the Prophets?": Protestant Influences upon the Annotated Bible of Isidore Clarius
}

\author{
R. GERALD HOBBS
}

\begin{abstract}
Summary: This paper attempts to recognize the important role played by Isidore Clarius in the reform of the Vulgate in the Sixteenth Century. In his preface, prolegomena and notes to the Bible, Clarius provided a form of pre-Tridentine Biblical scholarship which enjoyed more affinities with evangelical Protestant scholarship than with much of the Italian Biblical heritage. Isidore Clarius was one of the mitred abbots delegated by Paul III to the Council of Trent. In spite of his presence at Trent and his reputation as a scholar, Clarius could not escape the censorship which struck his Bible after the Index of 1564.
\end{abstract}

There is abundant evidence that for the two decades preceding the meeting of the Council of Trent, works of the Swiss and German Protestant Reformers, their biblical commentaries in particular, circulated easily in Italy. In particular, they were common currency in milieux marked by that evangelical humanism which sought a reform of the church effected through a return to the sources of the faith in Scripture and the writings of the Fathers. ${ }^{1}$ Nonetheless the demonstration of a conscious literary dependence by a father of the Council of Trent upon the Protestant Reformers of the upper Rhine valley could only underline the extraordinary theological diversity of that intellec-. tual climate described by Fenlon in his study of Reginald Pole. ${ }^{2}$ This paper will show this to be the case for the Benedictine mitred abbot, Isidore Clarius or Chiari, through an examination of his revised and annotated 'Vulgate' published in Venice in $1542 .^{3}$

Three centuries ago the sharp eyes of Richard Simon detected Clarius' dependence upon the work of Sebastian Münster, the Basel philologist, cosmographer and author of evangelical exegetica. ${ }^{4}$ In addition to his plagiarism of a known heretic, Simon reproached Clarius for methodological 
confusion. The abbot, in Simon's view, ought either to have produced a new translation of his own, or to have concentrated on purging the old of copyists' errors. Instead he had published a hybrid as unscientific as it was unsatisfactory. Since the Seventeenth Century those few persons who have given any attention to Clarius have contented themselves with a repetition of Simon's strictures. This paper will attempt, within severely defined limits, an initial examination of Clarius' work, with particular reference to his sources.

\section{Clarius and his Vulgata}

Taddeo Cucchi was born in 1495 in the northern Italian town of Chiari (Brescia); he adopted "Isidore" upon becoming a Benedictine in 1517; and "Clarius" in deference to his place of birth. ${ }^{5}$ Clarius' rise to the rank of abbot of Pontida in Bergamo was accompanied by a reputation for biblical scholarship. In 1536-37 Paul III named him to the papal Reform Commission where he was in close association with cardinal Contarini and his fellow Benedictine (and subsequent cardinal) Gregorio Cortese. During this period Fenlon identifies Clarius as a formative influence upon Reginald Pole, with whom he would enjoy further contact during the first years of Trent. ${ }^{6}$

Already known for his adhortatio ad concordiam, published in 1540 with a dedication to Contarini ${ }^{7}$, Clarius undertook the following year the most ambitious project of his career, a three-part annotated Bible, the Vulgata aeditio Veteris ac Novi Testamenti, which appeared in a handsome folio edition from the presses of Peter Schoeffer in Venice in $1542 .{ }^{8}$ It may be noted in passing that Schoeffer - a member of the well-known Mainz family of printers whose activity in Venice had begun only the previous year - had earlier been active in both Worms and Strasbourg in the printing of Reformation literature, including notably the so-called "Worms Prophets", the German translation of the Hebrew prophets by Ludwig Haetzer assisted by Hans Denck, both known for their radical Protestantism. ${ }^{9}$

In a three-page prefatory epistle to the reader, Clarius sets forth in elegant and limpid prose his motivation and working principles. What began as a private project shared with a few associates, is now, at the insistence of friends, being reluctantly submitted to the public. ${ }^{10} \mathrm{He}$ would have preferred the modesty of anonymous publication, had this not become of late a hallmark of heresy - a prudent observation, in the year of Paul III's reorganization of the Roman Inquisition. 
Clarius was moved to the present endeavour by his observation of two recurring deficiencies in the wealth of biblical commentaries both traditional and contemporary. In the first place

in the studied labours of all of these, that edition which the whole world uses - and I suspect always will - has not yet been freed from its present miserable condition. No one has taken the trouble to correct the errors with which it teems at every turn, a scandalous state of affairs considering that there exists in our day any number of persons who could have remedied this. ${ }^{11}$

Furthermore, although the Church's Bible has many passages in need of explanation, Clarius notes that few works do so within the compass of a single volume. Accordingly; his Vulgata will make conveniently accessible, to the general reader as well as to the specialist, a purified text accompanied by brief annotations. As these clear the obstacles from the comprehension of the letter, the devout reader will the more easily and joyously advance to meditation upon the spiritual truths of Scripture.

What principles does Clarius claim to have followed in the revision of the Latin Bible? In the first place, although he could have worked from the Hebrew sources himself, to avoid rendering his readers captive to personal idiosyncracies he has preferred to rely primarily upon the efforts of other scholars. These authorities were not however deployed without discrimination. Where the Hebrew seemed not to differ radically from the sense of the existing Latin, he preferred to retain the familiar, adding a note to enlighten the reader as to the difference with the Hebrew.

Had I chosen to work with goldsmith's scales instead of using the standard of popular usage, I should certainly have offended the ears of the Church, and I would not have accomplished my purpose, the preservation of the common edition. ${ }^{12}$

Such respect for tradition notwithstanding, Clarius felt himself obliged to revise or annotate in close to 8000 instances, and more, he confesses, remains to be done. It is however his hope that his work will prove a useful beginning upon which, with the blessing of the Church's leadership, others will build until the task is fully accomplished.

Several elements of this preface invite comment. Both style and content situate Clarius firmly in the camp of biblical humanism. The candor with which he unhesitatingly characterizes the defects of the received Latin makes clear his preference for the authority of the original tongues. Manifestly he had not been convinced by the arguments for the authority of the Church's 
Latin Bible made in 1529 by the Vatican librarian Agostino Steucho; for the latter the task of scholarship was essentially to restore the Latin to its pristine form purged of copyists' errors. ${ }^{13}$ It is more surprising to find no justification of his labours by appeal to the work of Jerome or Origen, or to the Council of Vienne which had decreed in 1311 the establishment of chairs of Semitic studies in five European centres, invocations common in the prefaces of renaissance biblical scholars. ${ }^{14}$ Similarly, there is no deference expressed for the interpretations of the Fathers. If this is honest in the light of his intention, viz. annotation in the light of the Hebrew, it also distinguishes him from more conservative Catholic biblical scholars like Richard of Le Mans. ${ }^{15}$ On the other hand, Clarius does not propose, as did his contemporary Santes Pagnini ${ }^{16}$, a completely new translation more faithful to the Hebraica veritas, the Hebrew original. ${ }^{17}$ Common sense told him the familiar Latin would continue to be the Church's Bible; his concern was to improve it in relation to the Hebrew sources. For pragmatic and pastoral reasons then, rather than "paring to the quick," 18 he would correct only where it was manifest that the traditional rendering had missed significantly the sense of the Hebrew.

The preface is followed by a catena of eight biblical quotations, an exhortation to the study of Scripture, while the final two pages of the prolegomena, under the title "Haec docent sacra bibliorum scripta" summarize the central truths of Scripture with a distinctly evangelical ring. Since we cannot know whether the inclusion of these pages was the decision of Clarius or of his printer, too much weight should not be placed upon their presence. In any event, their provenance was the 1532 Bible of the still eminently respectable Robert Estienne of Paris. ${ }^{19}$

Clarius' Bible was issued in three parts (though the three are bound together in every copy I have seen), of which the first contains Genesis to Job, while the second, with separate title-leaf, includes the remainder of the Old Testament. The deutero-canonical books of the Old Testament are in their traditional places in the Christian canon, not set apart at the end of the Old Testament as would become the Protestant fashion (if they were printed at all), and the much-loved Prayer of Manasses (destined ultimately to disappear even from Roman Catholic Bibles) appears at the end of Second Chronicles. Yet there are indications that Clarius was not unaffected by humanist criticism of the Christian canon. Prior to the first book of Samuel, he reproduces Jerome's prologue on canon with its expressed preference for the more restricted Jewish canon. Furthermore, while the Hebrew canonical books receive an annotation (in fine italic print) which occupies the bottom one-third of a typical page, the deutero-canonical books rarely have any notes at all. In 
an oft-censored paragraph appended to the first chapter of Ecclesiasticus, Clarius declines to undertake either text revision or annotation of that book, on the grounds that in its present Latin form it varies so radically from the Greek - he did not of course know the Hebrew version recovered only at the end of the 19th century - that any attempt to revise could only result in a wholly new translation. Annotation would therefore be impossible, unless one wished to philosophize upon this mass of errors, as too many exegetes had already done. ${ }^{20}$

The third and final part contains the New Testament followed by an addendum of two pages of additional notes and a 27-page "Index rerum et sententiarum", this too perhaps the publisher's responsibility.

\section{Clarius' Sources}

My attention was first drawn to the Clarius Vulgate by striking textual reminiscences of the work of the Strasbourg Reformer, Martin Bucer, on the Psalms. These suggested that Clarius might have used as sources more than the Münster Bible that Simon had detected, that perhaps this north Italian biblical humanist with known links to the reform movement in the Italian church might have had a particular affinity for the exegesis of the evangelical upper Rhineland school, that sodalitas of humanist Biblical scholars in Strasbourg, Basel and Zurich. ${ }^{21}$ Accordingly, this paper explores the hypothesis of such a connection by means of an examination of seven passages selected from the Old Testament ${ }^{22}$ with an eye to the range of biblical commentaries available in 1540 from the pens of the "prophets" (exegetes) of Strasbourg, Basel and Zurich. Limiting this study to the Old Testament, though it corresponds to what was for Clarius the principal task, leaves as a desideratum another examination of his New Testament revision and notes. ${ }^{23}$

\section{(a) Text revision}

(i) The first observation is that Clarius was working from a Vulgate of the Estienne 1532 family. In November of that year, Robert Estienne issued the second of his series of splendid Latin Bibles. ${ }^{24}$ As already in 1528, Estienne made extensive use of Carolingian manuscripts borrowed from St-Denis, St-Germain-des-Prés and the Sorbonne to complete a correction of the current text, his operating assumption being that those readings were preferable which corresponded more closely to the Hebrew. The 1532 Bible was quickly reproduced in several Lyon and Antwerp editions, any one of which Clarius may have possessed. In 1540, however, Estienne bowed to Sorbonne critics and in 
his folio Bible of that year returned to a more traditional form of the Vulgate, the variants in his manuscripts being indicated in the margin.

Clarius employed a small diacritical mark ( + ) to indicate his own revisions of the Vulgate text. A comparison of the other readings wherein his text differs from a common form of the received text shows that he is consistently following the Estienne 1532. ${ }^{25}$ Several other elements confirm the Estienne prototype. The only marginalia in Clarius' Vulgate are biblical cross-references which correspond at most points precisely to those of the Estienne edition. ${ }^{26}$ The division between chapters one and two of Hosea agrees with that in Estienne. ${ }^{27}$ Finally, the two prefatory tables referred to above are taken verbatim from Estienne 1532 , not 1540 , where their evangelical tone was significantly muted. ${ }^{28}$

The attraction of Estienne's Bible for our Benedictine abbot becomes more apparent when we compare the former's preface with that of Clarius. Like the latter, Estienne avoids attribution of the received text to St. Jerome. He is concerned to preserve and enhance the integrity of the Vulgate; but the many disparities between it and the Hebrew would trouble any reader setting it alongside one of the new translations. Accordingly Estienne has included a set of marginal notes gleaned for him by an unnamed scholar from Jewish as well as Christian sources, employing diacritical marks in the fashion of Origen and Jerome to identify for the reader the Latin's divergences from the Hebrew. Where, however, "our translation [i.e. the Vulgate] differs from the others only verbally and not in sense, no annotation is given." Furthermore no attempt has been made to annotate the books that lack a Hebrew original (i.e. the deuterocanonical) since their manuscript tradition was hopelessly confused. Now that the work is done, let the Church's leaders be judge of its utility. ${ }^{29}$

(ii) In the second place, Clarius does indeed introduce only a modest number of revisions into his Vulgate. In the 90 verses in our study there are about 20 changes indicated, while a further 14 are tacitly adopted (these last almost certainly from his model Estienne). As might be expected the poetry of the Song of Hannah and the Psalms is more frequently revised than is the prose of Genesis. Overall the ratio of revisions to verses is $1: 4.5$, or $1: 2.6$ if the tacit corrections be also included.

(iii) Who are these others whose lucubrations Clarius has borrowed? In first place Sebastian Münster, whose Hebrew-Latin Bible appeared first in $1534 .^{30} \mathrm{His}$ was not the first complete new translation of the Hebrew - that honour goes to the Dominican of Lucca, Santes Pagnini. ${ }^{31}$ But three features of Münster's Bible made it preferable for many readers to that of Pagnini: it set the Hebrew 
and new Latin translation in parallel columns, the Latin itself is less wooden and literal than that of Pagnini, and it was accompanied by a set of succinct annotations, many gleaned from rabbinic literature.

Next in importance is the multi-volume Bible with verse-by-verse commentary from the erstwhile Franciscan and teacher of Münster, Conrad Pellican. Since 1526 Pellican was teaching Hebrew Scriptures in Zurich. ${ }^{32}$ His Bible is at first sight a surprising item on Clarius' list of authorities. By the early 1540 's, there could have been no doubt of the heretical provenance of biblica printed by Froschauer of Zurich! Yet the origin of several revisions, particularly in selections A and B is beyond doubt; ${ }^{33}$ elsewhere over-lapping with other sources, particularly the Estienne, makes certainty difficult. In fact, Pellican would have been an attractive tool. Like Clarius, the former Franciscan remained committed to the ongoing place of the Vulgate in the church. Its elucidation by means of variant readings from the Hebrew (often placed in parentheses within the text) could be hoped to serve to perpetuate "the venerable authority of the popular translation amongst the Christian people." 34

Two other, relatively minor sources of revisions can be identified. The first is the paraphrased Psalter of Jan van Campen (Campensis), the second the massive commentary on the Psalms by Bucer of Strasbourg. Each of these is much more significant in the annotations and their discussion can be left until later.

(iv) What can be said of Clarius' use of these sources? First and foremost, he exercises his own judgement in their deployment. It is apparent that he often passes over emendations proposed by both Estienne and Pellican. He obviously dislikes the contemporary fashion of giving common names a more Hebraic form (e.g. Moscheh for Moses); and resists the impulse, for example, to turn the "paradise of pleasure" of Genesis 2,8 into the "Garden of Eden." Though he takes cognizance of the Hebrew interjection Selah in a note at Ps 3,5., 35 it is not introduced into the text of the Psalms, as is the case in Pellican, while Estienne inserts an asterisk at each occurrence. Hebraisms he avoids where their introduction would not contribute materially to the understanding of the literal sense. ${ }^{36}$

On two occasions he reminds the reader of his principle: "we learn in such passages to express the sense rather than the-words," an expression which locates him decisively on one side of the debate over the nature of biblical translation. ${ }^{37}$ On occasion he can retain a reading on what seem theological grounds. Thus at Ps 3,6 he retains "exsurrexi" with its Christological overtones, though "evigilavi" is given by Münster, Pellican and Estienne. ${ }^{38}$ Again he does 
not replace the "faciamus" spoken by the Creator at Gen 2,18 with "faciam" apparently preferring to retain the same form as that used in Gen 1,26; in this instance he does not even remark on the discrepancy, though all his sources urge the emendation.

On the other hand he can take bold action where he deems it warranted. In Psalm 14 there were in the Vulgate three units of text not present in the Hebrew: the phrase "non est usque ad unum" at the end of v.1; a catena of quotations (from other psalms and Isaiah 59) inserted after v.3 on the basis of its occurrence at Rm 3,13-18; and in v.5, a fragment "ubi non erat timor" imported from the parallel Ps 53,6. Perhaps because of its Christological application, Clarius does not follow his contemporary sources, retaining the offending member in v.1 without comment. The other two however are dropped, the former without even an explanation and in defiance of what more traditional scholars considered Pauline warrant for its inclusion. ${ }^{39}$

\section{(b) Annotation}

(i) Turning to the second of Clarius' tasks, we observe first that annotations occur with greater frequency than do text revisions. This is consistent with his operating principle, which called for him to avoid revisions not strictly necessary for the sense, drawing attention instead to the variant in the notes. Annotations of this sort are often but a few words, whereas those that elucidate difficult passages can be considerably more extensive. On the ninety verses in our seven passages, there are 59 formal notes, which become 72 when those that combine two or more verses are broken up. Moreover another seven are given in the 1557 edition. Thus the ratio of notes to verses is 1:1.14, approaching one per verse. ${ }^{40}$

(ii) Amongst Clarius' authorities, Sebastian Münster easily holds first place, figuring in about one-half the notes on Genesis, up to three-quarters on Samuel, though considerably less in some of the psalms. As might be expected this often takes the form of a gloss of the Hebrew not thought important enough to insert as a revision. In the prophets, Münster furnishes the historical introduction that begins the annotation of each book. From Münster too Clarius draws explanations of Hebraisms or of features of the ancient world, and occasionally a quote from the Targum or a mediaeval rabbinic comentator. Münster's brevity and clarity of style are such that on occasion, we find Clarius taking over the Basler's résumé of a Bucer comment, in preference to the more verbose form in which Bucer gave it. Very frequently Clarius uses Münster verbatim. ${ }^{41}$ 
Here too the commentaries of Conrad Pellican hold second place, though their contribution varies greatly from selection to selection. At places in the prophets Pellican seems behind one-half the notes; he contributes less in Genesis and Samuel, and very little in the Psalms. Pellican's format was a paragraph of comment per verse of text. From this Clarius occasionally lifted a phrase verbatim; more often he paraphrased an idea in his own words. This style of use makes identification of borrowings less simple than with Münster; there are occasions when one wonders if both authors may be reading a common source. Yet enough is certain to permit the observation that Clarius appreciated Pellican's combination of an historico-literal interpretation with moralistic observations, that he found attractive Pellican's emphasis upon Christ in the Old Testament and the displacement of Israel as people of God by the Church. On the other hand he usually ignores the Zuricher's allegorizing and hardly surprisingly, his Protestant propaganda. ${ }^{42}$

Pellican's absence in the Psalter, one discovers, is because Clarius went directly to the source Pellican himself had used liberally, the lengthy commentary on the Psalms by Martin Bucer of Strasbourg, published in 1529 and extensively revised and enlarged in 1532.43 The work, which broke important new ground with a fresh, very paraphrastic translation of the Psalms and a commentary based to a significant degree upon mediaeval rabbinic scholarship, had appeared under the pseudonym "Aretius Felinus of Lyon"; thus shielded from the accusation of heresy it circulated widely, and we should not be surprised to find Clarius possessing a copy. Obviously attracted by the work, Clarius borrowed heavily, in the process making his Psalms annotation much lengthier than for any other book. He begins each psalm with a statement of its theme, as a rule paraphrased from Felinus/Bucer, álbeit sometimes by way of Münster. A notable feature of Bucer's work is his quest for an historia, that historical moment that stimulated the composition of individual psalms, in whose light the details of the text may be expounded. From Bucer Clarius adopts a number, though by no means all of these; but their place in his notes is small. In this respect he is, like Pellican, more drawn to the Christological application of the Davidic materials. ${ }^{44}$ Yet conversely he is willing to follow Bucer - perhaps encouraged by Pellican and Münster's example - in the Strasbourger's rejection of the allegorical sense as primary in Psalm 19, despite the Pauline application of Psalm 19,5 to the preaching of the apostles in Romans $10 .{ }^{45}$ Bucer's rabbinic materials, his lexical studies, classical references and rhetorical criticism as well as his interpretive summaries are scanned with discrimination; his prolix and diffuse style is skillfully abbreviated and para- 
phrased, such that a page of the Strasbourger can be accurately summarized in a brief paragraph. 46

One other contemporary Hebraist makes the occasional appearance in the Psalms annotations. Jan van Campen (Campensis), professor at the Trilingue in Louvain, published at Nuremberg in 1532 a Paraphrase of the Psalter, after permission had been refused in Brussels. ${ }^{47}$ Widely appreciated, it reappeared in various guises, sometimes printed in parallel with the Hebraicum of St. Jerome, sometimes with the 1532 rendering by Zwingli! Campensis spent two years in Italy, for a time in the household of Reginald Pole, for a time in Rome under Contarini's patronage. He was thus almost certainly known personally to Clarius, who will have found Campensis' fervent biblical humanism and irenical zeal congenial with his own temperament. In the three psalms studied, phrases from Campensis occur on ten occasions.

Finally, the Estienne Bible, whose major role in the text revision has already been discussed, contributes also to the annotations, its marginal notes occurring from time to time as examples of alternative ways of translating the text.

(iv) Some general observations to conclude this section. The sources with which Clarius is working are never identified by name. This may be prudence, in the light of the taint of heresy that attached to several. It also corresponds, however, to his practice when he makes use of rabbinical materials found in Münster and Bucer. Unlike these two, who generally name the source they are quoting, Clarius falls back on the traditional "certain Jews," or simply cites without any reference at all. ${ }^{48}$

Although in the seven selections studied most of Clarius' sources were satisfactorily identified, there are some unresolved areas. In Isaiah in particular, he seems to have had a source beyond Münster and Pellican; could this have been notes from Campensis' lectures in Padua? ${ }^{49}$ In some notes Clarius himself added a classical reference. ${ }^{50}$ The tone of the annotations is uniformly irenical. If Clarius naturally omits Protestant propaganda, he is not interested in scoring the heretics. Thus although very attracted to Bucer's exposition of Psalm 19, when the latter disparages those neoterici who erect false dichotomies between Law and Gospel, Clarius ignores this mild barb directed at Luther and Bugenhagen.

One cannot conclude this discussion of the annotation without a word of comment on the absentees. If as we have seen, three leading exegetes of the upper Rhine school are amongst his authorities, others of their colleagues apparently were not. This I conclude from the fact that neither Oecolampadius 
nor Zwingli figures in the Isaiah annotation, nor is Capito present in Hosea. ${ }^{51}$ Equally striking is his failure to utilize the products of Italian biblical scholarship: Felix Pratensis and Agostino Giustiniani on the Psalter, Agostino Steucho on Genesis, and above all, the Bible of Santes Pagnini. ${ }^{52}$ For each, Clarius' reasons will have been different; that to all of them he preferred the product of north European scholars, several of whom were known Protestants, is remarkable.

\section{A Father of Trent}

Isidore Clarius was one of three mitred abbots delegated by Paul III to the council of Trent. Arriving in January 1546, after some procedural debate the abbots were seated with a single vote between them. ${ }^{53}$ In the light of the present study, we may appropriately ask what role Clarius played in the sessions of early 1546 on Scripture and the Church.

In the often fiery debates of February, ${ }^{54}$ the role of the three abbots is discreet. Clarius appears first by name in the Acta on May 20, when he argues in the name of the three for making primary the reading and study of Scripture in the monastic discipline, to the prejudice of scholastic theology. Subsequently he intervenes on several occasions in the justification debate. ${ }^{55}$ Clarius was of course recognized as an interested party in the biblical discussions. On March 1, Thomas Caselli, the Dominican bishop of Bertinoro, pointed to Clarius' Vulgate as an elegant example of what the church required, viz., not a new Bible but the correction of the old. ${ }^{56}$ Is there any evidence for Clarius' engagement in these debates?

In his useful but tendentious History of the Council of Trent, Paolo Sarpi reports an interesting intervention by Clarius, in which he is said to have presented an overview of the history of the Vulgate, arguing that it was a conflation of the work of Jerome and of the older Itala, and that it would be rash for the church to accord it an inspiration specifically disclaimed even by Jerome himself. Although no translation could ever equal the original Hebrew and Greek, he could acquiesce in a conciliar preference for the Vulgate, once it had been corrected against the originals. This would address the problem of the confusion created for the faithful by the host of new translations in circulation; a corrected official Vulgate would gradually bring these other translations into disuse. In the interim, the council might forbid the making of new ones. ${ }^{57}$

In an article published in 1905 Stephen Ehses rejected the authenticity of this speech, pointing out that Sarpi had set it in the congregation of the 
theologians on February 20 where, as a father of the council, Clarius had no place other than as an auditor. Furthermore he could speak in any event only as part of the triumvirate. ${ }^{58}$ Jedin has found the arguments of this article less than compelling in other respects. ${ }^{59}$ Without pretending to competence in the intricacies of the council, I note that the debates within the general congregation on April 1 and 3 record two interventions in the name of the abbots whose general tenor agrees with the speech in Sarpi. On the former day, while giving general approval to the decree on Scripture and tradition, the abbots include amongst other points that they would prefer not to ascribe the Psalter formally to David, nor do they like the formula pari pietatis affectu with its equation of the reverence due Scripture and tradition. ${ }^{60}$ Two days later in the debate on abuses and their remedy, the opinion of the abbots is recorded that to have a sole authoritative Vulgate must involve correction of the errors and corruption of the current text on the basis of the Hebrew and the Greek. Consistent with this respect for the Hebrew is their preference for omitting mention of the Septuagint in the decree. In the voting which followed the abbots supported Cardinal Pole's plea that the one official version of the Church be trilingual, that is, include the Hebrew and the Greek originals. On this they were in the minority. ${ }^{61}$

When the points raised by the abbots in congregation are compared with the preface and operating principles of Clarius' Vulgate on the one hand, and on the other with Sarpi's report, the overall consistency supports the general authenticity of the latter. Given Clarius' reputation as a biblical scholar and the favourable notice he had already received on the floor of council, it should hardly surprise if his two fellow abbots deferred to his expertise in the biblical debate. Ehses' argument that an individual abbot could not speak is disproved by the events of May $20 .{ }^{62}$ Thus, while Clarius was present at the congregations of theologians after February 20 only as an observer, as Ehses argues, it seems safest to conclude that Sarpi has brought together materials relating to both theological and general congregations of late-March and early-April 1546 which, while perhaps not strictly accurate minutes, represent responsibly the general tenor of the debate and the positions of the speakers, including that of Clarius.

The Council passed to other matters. For his part, the following January Clarius added to his responsibilities the diocese of Foligno, where he left the reputation of a reformer devoted to the pastoral formation of his clergy. Apparently he continued to find time for his studies, for a second edition of his Bible appeared in 1557, two years after his death, this time from the well-known Venetian firm of the Giunti. ${ }^{63}$ The title is changed, now reading 
Biblia sacrosancta veteris ac novi testamenti, the omission of "Vulgate" certainly due to the decisions of Trent with their requirement of an official text. A short preface is added, in which the reader is informed that this second edition "by popular demand" includes numerous additions to both text revision and annotation by Clarius himself. An "Ordo librorum" also appears with the prolegomena. In all other respects, however, these latter are untouched, so that Clarius' critique of the Vulgate in the original preface is intact. ${ }^{64}$

Two years later, however, the Index of Paul IV, like that of the Spanish Inquisitor General of the same year, listed the work of Clarius amongst its "Biblia prohibita". With the so-called Trent Index of 1564, this radical censure of a Father of the Council was made precise. The preface and prolegomena of Clarius' Bible were to be removed, and its title to allow no possible confusion of his text with that of the Vulgate. ${ }^{65}$ This limited censure accounts then for the existence of a third 'edition' of Clarius, dated 1564. While the new title page takes cognizance of the Tridentine strictures, the publisher in fact merely removed the offending four prefatory leaves from his existing 1557 stock, retaining the "ordo librorum", and put his Clarius back on the shelves. The copies I have examined retain the 1557 colophon. ${ }^{66}$

Although the 1564 Index made no mention of notes, these did not escape the scrutiny of vigilant censors elsewhere. The regularity with which certain passages - notably at Ps. 8,6, at Jeremiah 7,4 and the comments on the Ecclesiasticus text observed above - are blacked out in most surviving copies, show that they figured on someone's list of delenda. ${ }^{67}$

Seventeenth-century England looked upon Clarius with a kinder eye. He was among the exegetes of the previous century to find a new lease on life by inclusion in the voluminous Critici sacri, published at London in 1660, and subsequently reissued in Frankfurt at the turn of the next century.

This has been but a preliminary study. Nonetheless it suggests two concluding observations. First, the strictures of Simon and others notwithstanding, the place of Clarius needs to be recognized in the history of the Bible in the 16th century. In his struggle for a reformed Vulgate which should reflect faithfully the sense of the original, in his preference amongst contemporary exegetes for the work of the northern European humanists, he represented a form of pre-Tridentine Catholic biblical scholarship which because of its presuppositions found itself enjoying more affinities with some evangelical Protestant scholarship than with much of Italian biblica. The work of Roussel on Claude Guillaud of Autun ${ }^{68}$ suggests that there were others who shared these views, amongst whom we may name Estienne's Guillaume Fabritius and François Vatable. ${ }^{69}$ Theirs was of course the minority view at Trent, the 
application of whose decisions relegated their work, at least for Catholics, to the backshelves of archives. But there are insights to be gained too from the losers of historic confrontations. Which in turn reminds us that we have still much to learn about the complex of ideas, personalities and activities that was the reform party in Italy in the two decades leading up to the first period of the council of Trent. Any reply then to the question in the title of this paper, would do well to recall the ambiquity with which its biblical original was put (1 Sam. 10:11). At this juncture we can at least note that abbot Isidore danced discreetly before the Lord in the company of the Rhineland evangelical prophets.

\section{Vancouver School of Theology}

\section{Notes}

1. Such a definition would include Erasmian Catholics as well as persons more attracted to what became Protestant thought: e.g.in Naples and in Lucca in the groups around Peter Martyr Vermigli: Philip McNair, Peter Martyr in Italy (Oxford, 1967), 147-149. Cf. the letter of T. Quarterius to Martin Bucer, 22.10.1534 from Torino, in ed. J. V. Pollet, Martin Bucer: Études sur la correspondance (Paris 1958f.) 2,486. It seems that it is now also established that Juan Valdés drew upon German evangelical sources: Carlos Gilly, "Juan de Valdés: Übersetzer und Bearbeiter von Luthers Schriften in seinem Diálogo do Doctrina", ARG 74(1983) 257-305, esp.278-80 (Oecolampadius).

2. Dermott Fenlon, Heresy and Obedience in Pre-Tridentine Italy: Pole and the CounterReformation (Cambridge, 1977).

3. There is debate over the appropriateness of the term Vulgate applied to the Church's Bible before the Council of Trent. In this instance, it is the term Clarius himself chose for his edition of the Bible, a title subsequently censured by the Council.

4. Histoire critique du Vieux Testament (Rotterdam, 1685), 320-321. On Münster see infra, n.26.

5. Friedrich Lauchert, Die italianischen literarischen Gegner Luthers (Freiburg in $\mathrm{Br}$. 1912), \#27, 443-451; LTK 2, 1215; Enc. Catt. 3, 1771.

6. op. cit., 30-31.

7. Lauchert, $445 \mathrm{f}$.

8. Its full title: Vulgata aeditio Veteris ac Novi testamenti, quorum alterum ad Hebraicam, alterum ad Graecam veritatem emendatum est diligentissime, ut nova aeditio non facile desyderetur, et vetus tamen hic agnoscatur: adiectis ex eruditis scriptoribus scholiis, ita ubi opus est, locupletibus, ut pro commentariis sint: multis certe locorum millibus praesertim difficilioribus lucem afferunt. Authore Isidoro Clario Brixiano Monacho Casinate. Venetiis apud Petrum Schoeffer Maguntinum Germanum. Anno M D XLII. 
9. Alle Propheten (Worms, 1527). On Schoeffer, F.W.E. Roth, "Die Mainzer Buchdruckerfamilie Schöffer der Iungere in Basel und Venedig", Zentralblatt fur Bibliothekswezen 19 (1902) 456-459.

10. "...quod mihi duntaxat ac familiaribus meis usui esse posset": as well as friends. "Familiares" can be those of the household, perhaps the monks under his care.

11. Sign. iiv.: "Nam in his horum omnium studiis atque laboribus aeditio illa, qua totus Christianus orbis utitur - ac semper ut facile coniecto usurus est - nondum squallorem suum deposuerat, nec ei quisquam errores, quibus innumeris pene scatebat, adimere adhuc curaverat; quae res eo magis reprehensione digna mihi videbatur, quo eorum maior esset hac aetate copia, qui huic malo mederi potuissent."

12. Ibid. "si statera aurificis et non populari potius quadam trutina uti voluissem, offensae fuissent omnino ecclesiae aures, neque id quod cogitaveram esset consecutum, ut scilicet vulgata aeditio agnosceretur." The metaphor is from Cicero, De oratore 2,159.

13. In his Veteris Testamenti ad Hebraicam veritatem recognitio. Steucho would likewise be delegated to the Council of Trent. For his defence of Jerome's authorship of the Vulgate and its superiority to all other versions see the preface, fol. 84-85 (Venice 1591) v.1: "in qua editione si quid aut mendosum reperitur aut ab Hebraica veritate dissonum, aut additum aut detractum, vel nullius est momenti aut scriptorum vitio contigit”. Th. Freudenberger, Augustinus Steuchus, RGST 64/65, (Münster 1935).

14. Cf. e.g. Agostino Giustiniani, Psalterium Hebraeum, Graecum, Arabicum et Chaldaeum (Genoa 1516), pref. to Leo X (to Origen); Santes Pagnini, Biblia. Habes in hoc libro ... novam tranlationem (Lyon 1527-1528) pref. to Clement VII (to Jerome and the Council of Vienne). For the Vienne decree, see Corpus Iuris Canonici, ed. Friedberg, 2, 1179.

15. Richard Cenomanus, Collationes ad Psalmos (Paris, 1541) publ. as a companion to Peter Lombard's commentaries on the Psalter, and reprinted with them in MPL 191.

16. Above n.14. See Anna Morisi Guerra, "Santi Pagnini traducteur de la Bible", in Théorie et pratique de l'Exégèse. Actes du $3^{\mathrm{e}}$ Colloque International sur l'histoire de l'exégèse biblique au XVI ${ }^{\mathrm{e}}$ siècle, ed. Irena Backus \& Francis Higman, Geneva 1990, 191-198.

17. Jan van Campen in Louvain reported in 1532 the rumour that Clement VII had set a commission of six Christians and six Jews to the task (preface to his Psalter, see infra n.44).

18. Clarius: "Verum quod ad castigationes pertinet, consilium id fuit meum non ad vivum, quod aiunt, omnia resecare"; cf. Cicero, De amicitia 18, Loeb 126.

19. This leaf was frequently removed by censors from copies of both the 1542 and 1557 editions of Clarius. It can still be found in the copy in the Paris Bibliothèque Nationale, shelfmark A209. The source is Robert Estienne's Biblia (Paris, 1532), Sign. *iii r.v. Cf. Jürgen Quack Evangelische Bibelvorreden von der Reformation bis zur Aufklärung (Gütersloh 1975, QFRG 43), 117-120.

20. From a rare uncensored copy in the Bibliotheca Nacional, Madrid, Reserve, shelfmark U 4489: "Decreveram autem quod et Sapientia Salomonis feci, et hunc cum Graeco 
collatum emendare, sed ita multis locis inter se discrepant, ut susceptam provinciam in ipso initio deposuerim, nam fuisset potius novum librum facere et alium, pro eo qui in Latinorum manibus est, reponere. Cum ergo emendare non licuerit, multo minus obscuriora loca illustrare scholiis potui, quae non nisi ablatis a textu erroribus sunt adhibenda, ne, quod hactenus a multis factum est, in ipsis erroribus cogeremur philosophari (vol.2, p.137).

21. See B. Roussel, "De Strasbourg à Bâle et Zurich: une école rhénane d'exégèse (ca 1525 - ca 1540)", RHPR 68 (1988) 19-39; and Roussel and Hobbs, "Strasbourg et l'AEécole rhénaneAF d'exégèse (1525-1540), in BSHPF 135(1989) 36-53.

22. The texts chosen for this study are: (A) Genesis 2; (B) 1 Sam 2, 1-11; (C) Psalm 3; (D) Psalm 14(13); (E) Psalm 19(18); (F) Isaiah 1:1-12; (G) Hosea 1. Note that Hebrew (MT) and Vulgate traditions do not always coincide in chapter and verse divisions and numbering. In this paper I shall use throughout the MT system.

23. Since my initial writing of this paper, Maria Cristina Pauselli has begun study of Clarius' work on the New Testament under the direction of Dr.Irena Backus of the Institut d'Histoire de la Réformation in Geneva.

24. Cf. Biblia Breves in eadem annotationes, ex doctissimis interpretationibus et Hebraeorum commentariis ... Parisiis, ex officina Robert Stephani. M D XXXII. Cum privilegio Regis. Cf. Elizabeth Armstrong, Robert Estienne: Royal Printer (Cambridge 1954); Henri Quentin, Mémoire sur l'établissement du texte de la Vulgate (Rome, Paris 1922: Collectanea biblica latina, 6), p. 104-120.

25. In G, e.g. there are no identified revisions, but 5 readings that concur with Estienne 1532 against the traditional $\mathrm{Vg}$; in $\mathrm{F}$ the 3 variants not identified as revisions again concur with Estienne 1532. The reading at Hosea 1,2 is that of Estienne 1532 against Estienne 1540. For a standard $\mathrm{Vg}$ I have used the Brant text of Basel 1498.

26. In A, C, F and G exactly. At B they are omitted; at E there is an additional "Prov. 30.a" whose provenance I have not identified; at D Estienne has a series of 9 (relating to the catena from Rom. 3) which are reproduced with several errata and omissions.

27. After 1,11, as also in Pellican. The Brant Vg is after 1,9, as is the MT in the Venetian rabbinic Bibles; Münster is after 1,12.

28. Cf. supra n.19. A comparison of the indices may reveal further correspondences.

29. Ibid. Sign. *ii r.v. The "vir doctus aliquis" who worked for and with Estienne is identified in the 1540 preface as one Guillaume Fabritius, a canon of Poitiers.

30. En tibi lector Hebraica Biblia Latina Planeque Nova (Basel 1534). Karl H. Burmeister, Sebastian Munster. Eine Bibliographie (Wiesbaden 1964); on M. most recently see Jerome Friedman, The Most Ancient Testimony (Athens, Ohio 1983) passim.

31. Supra nn.14,16.

32. En damus tibi Christianissime lector Commentaria Bibliorum et illa brevia quidem.. - qui et Vulgatam commentariis inseruit aeditionem, sed ad Hebraeicam lectionem accurate emendatam ... (Zurich, 1532-39), 7 vols. Cf. Chr. Zürcher, Konrad Pellicans Wirken in Zurich, ZBRG 4 (Zurich 1975), 85-152. 
33. e.g. opportunus for similis sui at Gen 2,20.

34. See Pellican's defence of this preference in the preface (vol. 1, Sign. B 2v.-3r.) where he makes it clear that he would have preferred his Bible simply to have been printed with the Vulgate. On this debate within the Rhineland school, cf. Hobbs, "Ecole rhénane" 47-8.

35. Apparently overlooking the fact that its first appearance is two verses earlier.

36. Thus at $1 \mathrm{Sm} 2,5$, the barren continues to be promised "plurimos", not "septem" (as the Hebrew translates literally). Apparently Clarius was also not interested in promoting numerological speculations.

37. At Ps 19,4; also at Gen 2,1: both comments added in 1557 edition. On the debate, which opposed a reverence for the original (even to the word order) with an insistence on the necessity of translating sense to sense, see Hobbs, "Exegetical projects and problems: a new look at an undated letter from Bucer to Zwingli" in Prophet, Pastor, Protestant: the Work of Huldrych Zwingli after 50 years, ed. E. J. Furcha \& H. W. Pipkin (Allison Park, Pa. 1984), 94-96.

38. Clarius does note the issue in his annotations; but he is impressed above all by the providential application of these words concerning David to Christ.

39. On the handling of this textual issue by a variety of 16 th $\mathrm{C}$. exegetes, see Hobbs, "Hebraica veritas et traditio apostolica: St. Paul as interpreter of the Psalms in the 16th C." in ed. David C.Steinmetz, The Bible in the Sixteenth Century (Durham, NC, and London 1990),83-99.221-31.

40. These occur as follows (1542 \& 1557): A (25vv): $16 \& 2$; B (11vv): 11 ; C (9vv): $10 \&$ 2; D (7vv): 5; E (15vv): 12 \& 1; F (12vv): 8 \& 1; G (11vv): 10 \& 1.

41. E.g. at Gen 2,11-14, Clarius excerpts verbatim a note on the identification of two of the rivers, omitting the material on the Tigris, presumably because it was better known. At Ps 19, the introduction to the Ps is Bucer, in part paraphrased by Clarius, in part by Münster whence it is taken up verbatim.

42. At Gen 2,16-17 he does not use Pellican's allegorical treatment of the Garden. Later at 2,18 he likewise passes over Pellican's comments on the evils of enforced celibacy; he does however paraphrase Pellican's comment that the replacement of the man's rib by flesh after the making of woman $(2,21)$ symbolizes the diminishing of virility that comes through intimacy with women!

43. Sacrorum Psalmorum libri quinque [Strasbourg] (1529); cf. Hobbs, "How firm a foundation: Martin Bucer's historical exegesis of the Psalms" in Church History 53 (1984) 477-491. I am at work on a critical edition of his work for the Martini Buceri Opera Latina (Leiden, SMRT).

44. E.g. at Ps 3, for his introduction Cl. excerpts from Bucer on David's perils at the hands of Absalom, and his composition of the psalm "suo exemplo ad fidendum Domino provocare". In 1557 he adds a sentence loosely based upon Bucer (or Pellican's abridgement of him) underlying the typological application of the text to Christ. In Psalm 3, the historia has of course canonical warrant (v.1). At Ps 2, Cl. accepts an 
hypothetical historia proposed by Bucer; on the other hand he makes no mention of Bucer's proposal for Ps 14.

45. Clarius makes extensive use of Bucer on this psalm; there are 13 lines of biblical text for 66 lines of notes (by comparison the following psalm has a ratio of 8:12). Amongst the materials borrowed, Bucer's discussion of the correct way to relate the Old Testament to the New.

46. The note at Ps 19,5 (Soli posuit) is a good illustration. The opening statement, of the superiority of the sun to any star is Bucer digested by Münster; the comparison of the sun to a bridegroom and a striking reference to contemporary Jewish wedding customs are verbatim Bucer; a reference to John 3,29, the simile of a runner with a quotation from Homer and cross-reference to Ps 18,34, and comment upon the elegance of the simile and its lesson for us, all follow in succession from Bucer, partly verbatim, partly paraphrased.

47. Psalmorum omnium iuxta hebraicam veritatem paraphrastica interpretatio (Nuremberg 1532). On Campensis see H. De Vocht History of the Foundation and Rise of the Collegium Trilingue Louvaniense, 3, 158-208 (Louvain 1954 Humanistica Louvaniensia, 12).

48. So at Gen 2,3 (from Münster) and the intro. to Ps 14 (from Bucer). The exception seems to be the translations from the Targum: Hos 1,22 ("Jonathan"), or often "Chaldaeus."

49. Fenlon, op. cit. 30.

50. At Gen 2,19 where he adds "opinor ex hoc loco Platonem venisse in eam opinionem . . ." on the naming of earth's creatures; at 2,11 he adds a Homeric reference to a note otherwise from Münster.

51. For these and other commentaries of the Rhenish evangelicals, see Roussel, "De Strasbourg", p. 37.

52. Felix Pratensis, Psalterium ex hebreo diligentissime ad verbum fere tralatum (Venice 1515); on Steucho, supra n.13; Giustiniani \& Pagnini, n.14.

53. H. O. Evennett "Three Benedictine abbots at the Council of Trent" in Studia Monastica1(1959) 343-377.

54. On the Scripture issues before the Council, H. Jedin, Geschichte des Konzils von Trient 2 (Freiburg in Br. 1957) chap. 2.

55. Stephen Ehses, "Zwei Trienter Konzilsvota ... Isidorus Clarius", Römische Quartalschrift 27(1913), Geschichte, 25-28.

56. Concilium Tridentinum: Diariorum, Actorum ... Nova Collectio, (Freiburg in Br. 1901f.), v.1 :Diarium III (Massarelli) p.507.

57. Histoire du Concile de Trente (Bâle 1738), 1, 278-280.

58. "Hat Paolo Sarpi für seine Geschichte des Konzil von Trient aus Quellen geschöpft die jetzt nicht mehr fliessen", Historisches Jahrbuch 26(1905) 313.

59. op. cit. 458 n. 15 . 
60. Conc. Trid. 5, 46.

61. Ibid. 63.65-66.

62. Ibid., 149-150.

63. Apparently the heirs of Luc Antonio Giunti: Cf. G. Fumagalli, Lexicon typographicum italiae (Firenze 1905) 141-143.462-468.

64. Contrary to Lauchert, op. cit. 443-445.

65. Fr. H. Reusch, Die Indices Librorum Prohibitorum des Sechszehnten Jahrhunderts, (Tübingen 1886) p. 207.217.247-248.

66. In the BN, Paris, shelf no. A212; in the BN Madrid, no. 1/43 781 .

67. The Ecclesiasticus is given supra n.20. The Ps. 8:6 (taken from Bucer) reads: "Nam hanc dignitatem, qua caeteris dominemur, ob peccatum magna ex parte amissam, Christo credentes recipimus". From Jer. 7 (paraphrased from Münster): "Ait ergo propheta exteriorem cultum Dei minime gratum esse Deo, si interim pessime vivatur".

68. "La formation biblique du clergé d'Autun entre 1540 at 1550: Bucer plagié, le chanoine Guillaud censuré. Recherches nouvelles sur Claude Guillaud (1493-1551) Théologal d'Autun", in Horizons européens de la Réforme en Alsace ... (Strasbourg: Istra 1980) 313-337.

69. See D.Barthélemy, "Origine et rayonnement de la 'Bible de Vatable"” in Théorie et pratique de l'Exégèse, ed.I.Backus \& F Higman, EPH 43 (Geneva 1990), 385-401. 